\title{
THE ZOOPLANKTION FAUNA OF BHAGALPUR (BIHAR) II. CLADOCERA
}

\author{
With 9 Figures
}

by

\begin{abstract}
S. A. K. NASAR*
(Post-Graduate Dept. of Zoology, Bhagalpur University, Bhagalpur, Bihar 812001, India)

インド, バガルプール地方（ビハール州）のプランクトン動物相 II. 枝角類 插図 9

\author{
S. A. K. ナザール
}

(パガルプール大学, インド)

Abstract: This paper is the outcome of a survey of Cladocera fauna of Bhagalpur (India). The number of species recorded were eleven from among five genera. All the species recorded in this paper are new record for Bihar, except Moina dubia GUERENE \& RICHARD and Ceriodaphnia rigaudi RICHARD. Regarding the zoogegraphical disrtibution of the cladocera of Bhagalpur, India it appears that it has greater affinity with South-East Asian, Australian and African fauna than the Palaeartic fauna.
\end{abstract}

\section{Introduction}

As the cladocera constitute a major item of fish-food, their study is of utmost importance for the proper development of fisheries. Our earlier knowledge of the cladocera (Arthropoda: Crustacea) fauna of Bihar was almost scanty, and even of India as a whole, very meagre. After the papers of BREHM $(1963,1950,1953)$, SEwELL (1935) and NAYAR (1971) there are no important works worth mentioning.

The report is based on the collections made from the freshwater ponds of Bha-

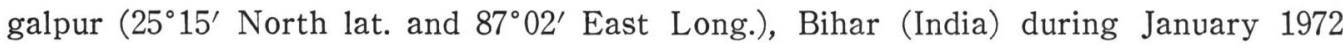
to December 1974. In a earlier paper, I have already described the rotifers, present in those collections (NASAR, 1973).

* Present address: Dept. of Zoology, School of Life-Sciences, North Eastern Hill University, SHILLONG-793003, Meghalaya (India) 


\section{Abiotic environment}

Meteorological condition: The meteorological data is obtained by the Sabour Meteorological Station, Bhagalpur situated about 6 Kilometer from the studied area.

The mean maximum and minimum temperature varied from 23.3 to $44.0^{\circ} \mathrm{C}$ and 7.3 to $24.7^{\circ} \mathrm{C}$ respectively. The rainfall ranged from nil to $464.0 \mathrm{~mm}$ during the period of this study. The humidity varied from 29.0 to $89.0 \%$.

Physico-chemical condition: Table 1 gives the range of the physico-chemical factors of the water bodies (NASAR, 1975) from where the cladoceran were collected.

Table 1. Physico-chemical factors of the water bodies (January 1972 to December 1974)

\begin{tabular}{l|r|r|r|r}
\hline \multicolumn{1}{c|}{ Factors } & TNB Pond & $\begin{array}{c}\text { Hathkatora } \\
\text { pond }\end{array}$ & Bharwa pond & Bhatta pond \\
\cline { 1 - 2 } Temperature $\left({ }^{\circ} \mathrm{C}\right)$ & $25.0-37.5$ & $27.3-39.4$ & $27.1-37.6$ & $26.5-39.0$ \\
Transparency (cm) & $50.8-84.5$ & $5.5-21.5$ & $24.0-95.0$ & $34.2-92.0$ \\
Dissolved oxygen (mg/1) & $3.2-15.8$ & $3.7-9.8$ & $4.2-10.3$ & $4.4-9.9$ \\
pH (unit) & $6.8-8.5$ & $6.5-8.7$ & $6.9-8.9$ & $7.2-8.3$ \\
Free CO (mg/l) 2 & $0.0-8.0$ & $0.0-10.0$ & $0.0-2.0$ & $0.0-0.0$ \\
Total Alkalinity (mg/1) & $76.0-160.0$ & $46.0-108.0$ & $64.0-130.0$ & $80.0-196.0$ \\
Total hardness (mg/l) & $90.0-125.0$ & $78.0-124.0$ & $106.0-155.0$ & $100.0-164.0$ \\
\hline
\end{tabular}

\section{Description of the species}

Daphnia carinata KING 1853 (Fig. 7)

Rostrum and antennule pulex like but front not sinuate. Head carinated. Postabdomen tapered and not sinuate. WAGLER (1926) synonymised $D$. similis Claus.

Distribution: India-Rajasthan, Panjab, U.P., Gujrat, Mysore and Bihar (present record). Elsewhere-Cylone and Australia.

D. lumholtzi SARS 1885 (Fig. 9)

A thin carapace and the head often drawn out into a point anteriorly. Postabdomen has a sinerate dorsal margin with 11-13 anal denticles ending in well developed claws. The first and second abdominal process are well developed without any hairs.

Distribution: India-Rajasthan, U. P., Bengal, Madras, A. P. and Bihar (Present record). Elsewhere-Pakistan, Cylone, Palestine, Syria Egypt and Australia. D. pulex (De GEER) 1778

Head and carapace from brond oval. Anterior margin of head concave. Distribution: India-Bihar (present record). Elsewhere-America. Simocephalus vetulus ScHodle 1885 (Fig. 3)

Frons rounded, ocellus elongate. Carapace markings as obliqueparallel lines and usually without carapace-spine. 
Distribution: India-Panjab, Rajasthan, U.P., Kashmir and Bihar (present record). Elsewhere-England, Switzerland, Russia and America.

S. elizabethae (KING) 1852 (Fig. 4)

Valves transversely striated. Postabdomen broad with indentation in which anus opens. Body not symmetrical. Posterior prominence very prominent. The species differes from $S$. vetulus (O.F. Muller) in the shape of its posterior boarder of the carapace.
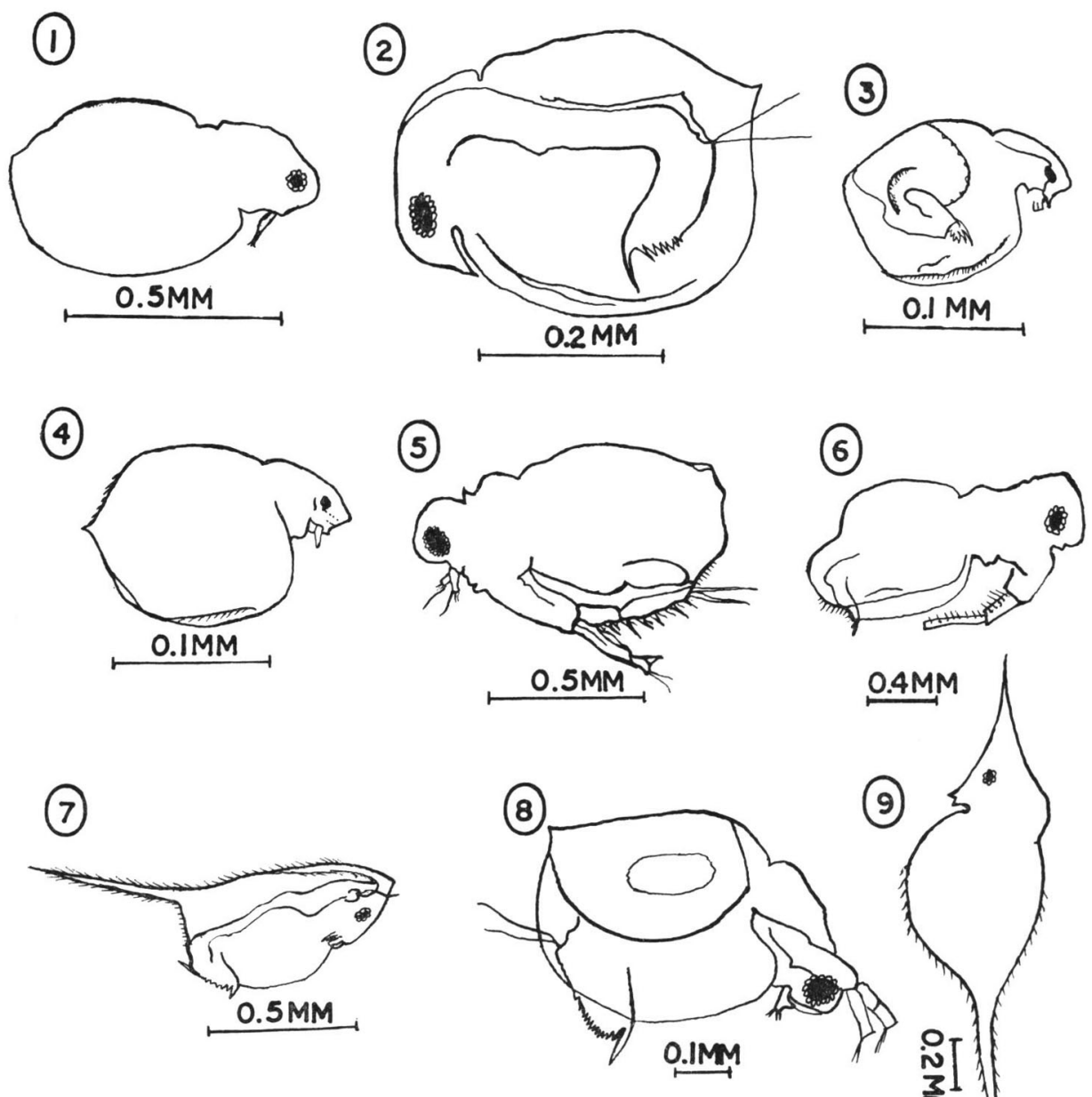

(9)

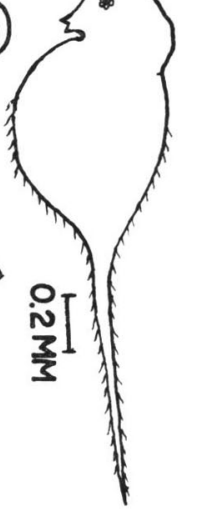

Fig. 1. Moina dubia. Fig. 2. Ceridaphnia rigaudi. Fig. 3. Simocephalus vetulus. Fig. 4. Simocephalus elizabethae. Fig. 5. Diaphanosoma sarsii. Fig. 6. Diapha. nosoma exicum. Fig. 7. Daphnia cainata. Fig. 8. Ceriodaphnia reticulata. Fig. 9. Daphnia lumholtzi. 
Distribution: India-Rajasthan, Bengal, M. P. and Bihar (present record). Elsewhere-Cylone, Thailand, Sumatra, Jawa and Australia.

Moina dubia GUERENE \& RichARD 1892 (Fig. 1)

The proximal part of ventral margin valves with strong spines, the distal part with groups of spinules, the proportion 1:2 of the reduced distal part to the broad proximal part of the post-abdonmen. Acessory ridge on the end-claw absent. The head depression at an angle of $70^{\circ}$.

Distribution: India-Rajasthan, Bengal and Bihar. Elsewhere-Australia, Africa, Jave and Europe.

Ceridaphnia rigaudi RICHARD 1894 (Fig. 2)

Antennules small, valves oval and rounded. No post-anal extension of post-abdomen. Prsence of short spine or horn on its head infront of the antennules. Two abdomen processes. Post-abdomen with 5-6 anal spines. Claws smooth or denticulate.

Distribution : India-West Bengal, A. P., Mysore, Gujrat, M. P. and Bihar. ElsewhereJapan, Egypt, S. Africa and South America.

C. reticulata (JURINE) 1820 (Fig. 8)

Reticulation of the shell is not distinct. There are only 3-7 anal denticles on the postabdomen and a pecten of 5 teeth. Indistinct reticulation on the shell. Head without spine. Claws pectinate.

Distribution : India-Rajasthen and Bihar (present record). Elsewhere-South America. Diaphanosoma excisum SARS 1885 (Fig. 6)

The species is easily recogonisable from allied species by its shorter and the absence of hairs on the sides of postabdomen. Body is more robust and the superoposteal angles are markedly deflected.

Distribution: India-Rajasthan and Bihar (present record). Elsewhere-Australia. D. exicum var. longrimsis EKMAN 1904

This variety very much resembeles with $D$. exisum var. stinglini Jenkin in the presence of hairs at the sides if the postabdomen and with the type in the number of setae on the carapace border, but differs from it in the greater length of the antennae which surpass the posterior boarder of the carapace.

Distribution: India-Rajasthan, West Bengal and Bihar (present record). Elsewhere-Summatra and Aferica.

D. sarsii RICHARD 1895 (Fig. 5)

The species differs from $D$. exisum and its varities mainly by the greater breadth of the shell-duplicator and more spines at its infero-posteal corner.

Distribution: India-Rajasthan, M. P., and Bihar (present record). ElsewhereCylone, Africa and South America. 


\section{Acknowledgments}

The autor is indebted to Professor J.S. Datta Munshi, Dean faculty of Sciences, Bhagalpur University for valuable guidance and to the Director, Zoological Survey os India for help in identification of the zooplankton.

\section{References}

Brehm, V., 1936: Report on Clandocera (Yale North India Expidition). Mem. Conn. Acad. Sci., New Haven, 10, 293-297.

1950: Contribution to the freshwater fauna of India. Part II. Rec. Indian Mus., Calcutta, 2, 327-330.

1953: Indische Diaptomiden, Pseudodiaptomiden and Caldocera. Ost. Zool. Z. Wien., 3, 241-345.

Brooks, J.L., 1956: The systematics of North American Daphnia. Mem. Conn. Acad. Arts. Sci., New Haven, 13, 1-180.

NASAR, S.A.K., 1973: The zooplankton fauna of Bhagalpur: I. Rotifera. J. Bh. U (N.S.)., 6, $55-62$.

1975: Studies on some aspects of pond ecosystem at Bhagalpur. Ph. D. Thesis, Bhagalpur University, Bhggalpur, India.

NAYAR, C.K.G., 1971: Cladocera of Rajasthan. Hydrobiol., 37, 509-519.

SEwell, R.B.S., 1935: Studies on the bionomics of freshwaters of India II.

WAGler, E., 1926: Die systematik und geographische Verbreitung des Genus Daphnia. Arch. Hydrobiol., 30, 505-556.

\section{摘 要}

インドに括ける枝角類の知識は貧弱である。筆者は1972年 1 月から 1974年12月にかけて，バ ガルプール地方にある 4 つの池について, 枝角類と池の無機的環境の調査をした。その結果 5 属11種が採集され, Moina dubia GUERENE \& RICHARD, Ceriodaphnia rigaudi RICHARO の 2 種以外はこの地方では始めての記録である。調査した種類は，これらの分布からみると， 東南アジア・オーストラリア・アフリカなどの動物相と類縁関係にある。 